\title{
IDENTIFICATION OF PROTEIN FRACTIONS OF MILK COWS CASEIN COMPLEX
}

\author{
A. V. IUKALO \\ Ternopil Ivan Puluj National Technical University, Ukraine; \\ e-mail: biotech@tu.edu.te.ua
}

To date, dozens of biologically active peptides formed during proteolysis of casein fractions have been discovered. The use of these peptides is closely related to the necessity of their rapid identification. The aim of this work was the development of an electrophoresis system for rapid identification of individual fractions in serial studies and the separation of the milk casein complex. Considering the abnormal nature of the interaction of caseins with the sodium dodecyl sulfate and similar values of their molecular masses, the anode electrophoresis system in a homogeneous polyacrylamide gel was taken as a basis. Caseins, in this system, are separated according to their charge and located on the electrophoregram in accordance with the modern classification. Urea was used as a disaggregating agent in gel. It was shown that the use of Studier type apparatus for electrophoresis with changeable dimensions of electrophoretic chamber significantly reduces (to $45 \mathrm{~min}$ ) the time for identification of casein fractions. This method may be useful for rapid identification of casein fractions, as well as for rapid analysis of natural milk and milk products.

Key words: casein, electrophoresis, identification of protein fractions, milk cows.

$\mathrm{P}$ roteins of milk casein complex have a heterogeneous complex nature [1], which is caused by: 1) the differences in the primary structure of the four main fractions $\left(\alpha_{\mathrm{S} 1}-\mathrm{CN}, \alpha_{\mathrm{S} 2}-\mathrm{CN}, \beta-\mathrm{CN}\right.$ and $\kappa-\mathrm{CN}$ ); 2) limited proteolysis of $\beta-\mathrm{CN}$ during milk synthesis by a natural protease, plasmin (EC 3.4.21.7), forming three polypeptides $\gamma^{1}-[\beta-C N-$ $1 P(f 29-209)], \gamma^{2}-[\beta-C N-1 P(f 106-209)], \gamma^{3}-$ $[\beta-C N-1 P(f 108-209)]$, that were incorrectly attributed to the individual casein fractions, 3) the differences in the amount of phosphorylated serine residues, resultant from which there are two groups of milk casein: $\alpha_{\mathrm{S} 1}$ - and $\alpha_{\mathrm{S} 0}-\mathrm{CN}$ (based on the primary structure of $\left.\alpha_{\mathrm{S} 1}-\mathrm{CN}\right)$ and $\alpha_{\mathrm{S} 2}-, \alpha_{\mathrm{S} 3}, \alpha_{\mathrm{S} 4}{ }^{-}$and $\alpha_{\mathrm{S} 6}{ }^{-}$ $\mathrm{CN}$ (based on the primary structure of $\alpha_{\mathrm{S} 2}-\mathrm{CN}$ ) and, finally, 4) the differences in structure and number of oligosaccharide groups in $\kappa-\mathrm{CN}$. All of the described above causes the existence of one main phosphoprotein $(\kappa-\mathrm{CN})$ and nine minor phosphoglycoproteins. Moreover, at a time they can range from 3 to 5 in the milk from one animal.

The problem of identification of casein fractions is closely related to study of their main function, that is, providing the mammalian with protein nutrition in the postnatal period. To date, several dozens of bioactive peptides have been isolated from different casein fractions [3]. Some of them are already used as supplements and functional ingredients.

To identify the proteins of the casein complex, electrophoretic techniques are often used [4-6]. However, the most common electrophoresis systems for protein analysis in polyacrylamide gel (PAGE) with sodium dodecyl sulfate (SDS) have proved to be ineffective. This is caused by the abnormal interaction of casein fractions with SDS, as well as by the similar molecular mass values of the individual fractions of $\alpha_{\mathrm{S} 1}{ }^{-}$and $\alpha_{\mathrm{S} 2}$-casein groups [1]. Anode systems for electrophoresis in the presence of urea allow identifying casein fractions in accordance with the modern classification [7]. However, these systems are not designed for rapid analyses of the large number of samples and their main disadvantage is the long duration of the analysis.

The aim of this work was to develop electrophoresis systems for the rapid identification of the protein fractions of the milk casein complex.

\section{Materials and Methods}

In our experiments we used preparations of total casein isolated from fresh skimmed milk cows by isoelectric point precipitation followed by inactivation of natural proteases [6]. Individual casein 

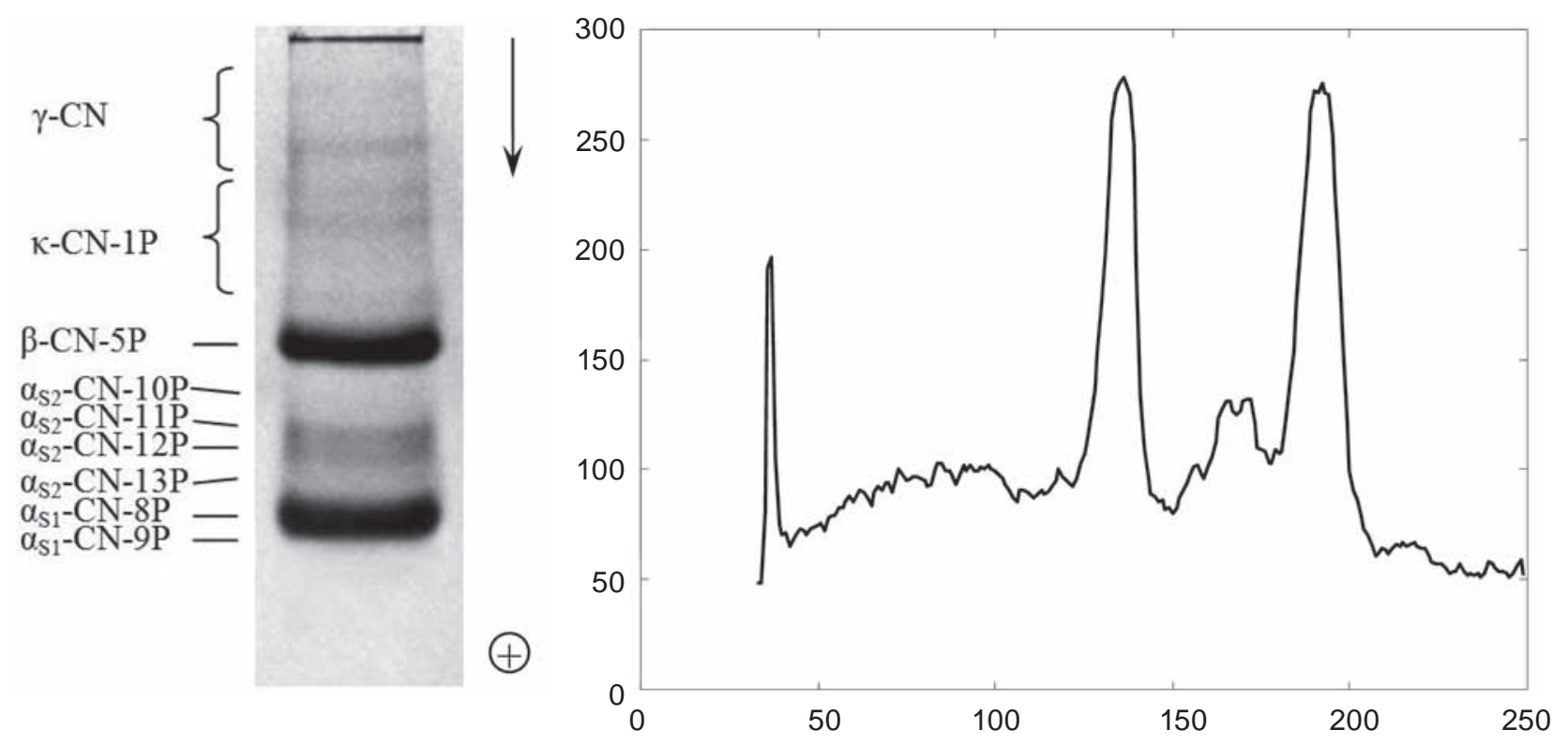

Fig. 1. Electrophoregram and densitogram of the sample of total milk casein

fractions were isolated by preparative electrophoresis as described [9]. Dry whey protein concentrate ("KSB") was provided by Buchatsky cheese factory (Ukraine). Soy protein isolate (Ukraine) was also used.

Protein concentrations were determined using a spectrophotometer SF-46 $(\lambda=280 \mathrm{~nm})$. Previously determined absorption coefficients for different casein fractions ( $\left.\mathrm{D}^{1 \%}{ }_{1 \mathrm{~cm}}\right): 10.0$ - for $\alpha_{\mathrm{S} 1}$-casein; 4.6 - for $\beta$-casein; 9.6 - for $\kappa$-casein and 8.2 - for total casein were used [1].

Fractional composition of total casein and homogeneity of its fractions were analyzed by vertical polyacrylamide gel electrophoresis in Studier apparatus. We used an alkaline buffer gel system as described previously [7]. Electrophoregrams were fixed and stained using standard methods. Electrophoretic buffers and gels were prepared using reagents (Reanal, Hungary and Sigma, USA). All other reagents were of domestic production (chemical and high purification). Densitograms of the electroforegrams of total casein and its fractions were created using image reader of MatLab imread, as described [10].

\section{Results and Discussion}

Previously described PAGE anode system in the presence of urea [7] was taken as the basis for the method for rapid identification of proteins of casein complex. This system proved to be successful in the composition analysis of milk proteins, the study pathways of bioactive peptides formation from milk casein, and modeling of enzymatic casein coagulation during milk nutrition. The homogeneous PAGE anodic system for casein analysis is also recommended by Committee on Nomenclature and Classification of milk proteins [1]. The result of the electrophoresis of total milk casein in this system is shown in Fig. 1.

It can be seen on the electrophoregram the characteristic distribution of all known casein fractions in accordance with the international classification. It is possible to identify more than 13 fractions. In milk from various animals, the number of casein fractions can range from 13 to 15 , depending on the

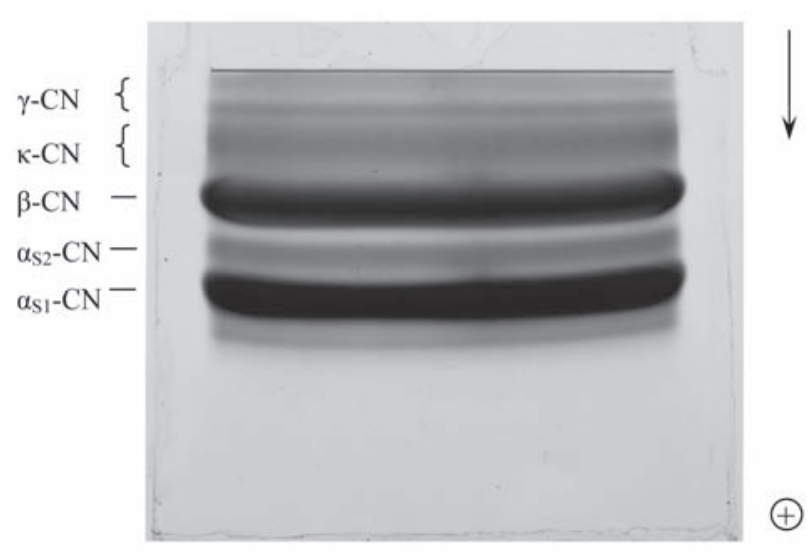

Fig. 2. Gel slab after preparative electrophoresis of the proteins of milk casein complex 
A

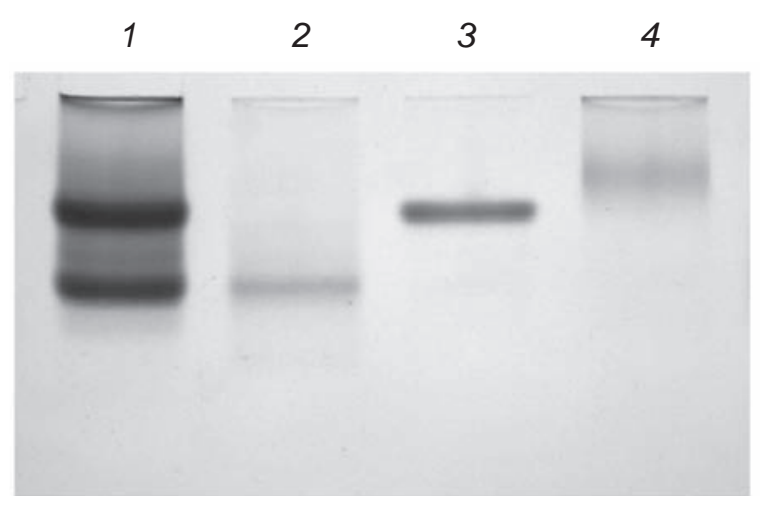

B

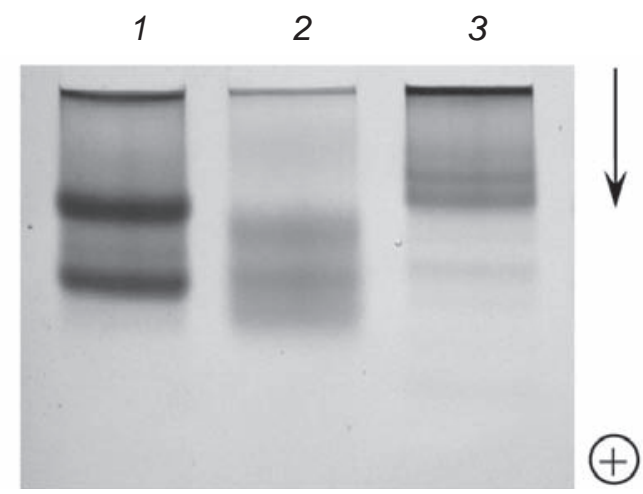

Fig. 3. A - electrophoregram of total casein (1) and its fractions: $\alpha S 1-C N(2), \beta-C N$ (3) and $\kappa-C N$ (4). $B$ - electrophoregram of total casein (1), whey proteins (2) and soybean proteins (3)

number of $\kappa$-caseins which differ in the content of negatively charged oligosaccharide groups.

Previously isolated homogeneous $\alpha_{\mathrm{S} 1}-, \beta$-, and $\kappa$-caseins were used as markers for the casein identification. Isolation was performed by preparative electrophoresis [9]. The staining gel slab after preparative electrophoresis of the proteins of milk casein complex is shown in Fig. 2.

The obtained samples of total casein and its main fractions were used for the further study. To develop methods for rapid caseins identification, the apparatus for vertical polyacrylamide gel electrophoresis (Studier type) was made in the Laboratory of Milk Protein Biochemistry (TNTU). The design of the apparatus allows changing the geometric dimensions of the chamber and the number of samples for simultaneous analyses. The improved former design provides a high-quality electrophoresis. Thus it guarantees the absence of such a defect as a "veil" when the samples fall between the gel slab and the chamber wall. The deformation of the protein bands in the edge tracks is also decreased.

While optimizing the electrophoresis systems [7] the following changes have been made: $\mathrm{pH}$ of buffers for the gel as well as for the studied samples and the electrode buffer was increased up to 8.3 ; PAG concentration was reduced to $3.3 \%$; $\beta$-mercaptoethanol was removed from the buffer for the gel and the protein samples; electrophoresis chamber dimensions were reduced. The absence of $\beta$-mercaptoethanol does not affect the quality of separation, since minor fractions containing cysteine residues ( $\kappa$ - and $\alpha_{\mathrm{S} 2}$-casein) move in one band. Before analysis, protein samples were dissolved in buffer which was identical in composition to the gel buffer and contained 20\% sucrose. Protein samples $0.5 \%$ for the total casein and $0.1 \%$ for casein fractions were pipetted into the wells underneath the buffer. The criteria for establishing the duration of the electrophoresis (30 min.) was a minimal separation of $\alpha_{\mathrm{S}^{-}}, \beta-, \alpha_{\mathrm{S} 2}{ }^{-}$and $\kappa$-casein fractions, which was controlled by densitograms. Staining with intensive shaking carried out for $1.5 \mathrm{~min}$ is sufficient. The main casein fractions can already be identified 10-15 minutes after the standard gel washing. High-quality electrophoregram for quantitative analysis can be obtained after 90 minutes. Electrophoretic distaining can be used if necessary to reduce the time of the analysis. The best result of rapid electrophoretic identification of total casein and its fractions is shown in Fig. 3, $A$.

It is also important that the whey and soybean proteins, often used to substitute casein, differ in electrophoretic mobility in the proposed electrophoresis system. Electrophoregram of total casein, whey proteins and soybean proteins is shown in Fig. 3, B.

Thus, the proposed anodic electrophoresis system in a homogeneous PAG in the presence of urea can be used for rapid analysis and identification of the proteins of the milk casein complex, in particular during their isolation and purification. 


\section{ІДЕНТИФІКАЦІЯ ПРОТЕЇНОВИХ ФРАКЦІЙ КАЗЁ̈НОВОГО КОМПЛЕКСУ МОЛОКА КОРІВ}

\section{А. В. Юкало}

Тернопільський національний технічний університет імені Івана Пулюя, Україна; e-mail: biotech@tu.edu.te.ua

На сьогодні відомо ціла низка біологічно активних пептидів, які утворюються в процесі протеолізу різних казеїнових фракцій. Використання цього протеїнового комплексу, враховуючи складну гетерогенну природу казеїнів, тісно пов'язане з необхідністю його оперативної ідентифікації. У зв'язку з цим метою роботи було створення електрофоретичної системи для швидкої ідентифікації окремих фракцій під час серійних досліджень казеїнового комплексу. Враховуючи аномальний характер взаємодії казеїнів 3 додецилсульфатом натрію та близькі значення їхніх молекулярних мас, за основу була взята анодна система електрофорезу в однорідному поліакриламідному гелі. У такій системі казеїни розділяються за їхніми зарядами та розташовуються на електрофореграмі відповідно сучасній класифікації. Як дезагрегуючий агент до складу гелю додається сечовина. На основі проведених досліджень на виготовленому в лабораторії приладі типу Стадієра зі змінною формою електрофоретичної камери встановлено умови швидкої ідентифікації казеїнових фракцій. При цьому було змінено склад гелю і скорочено термін, що дозволило вже за 45 хв ідентифікувати основні фракції казеїнів. Метод може бути корисним для оперативної ідентифікації фракцій казеїну та за експрес-аналізу натуральності молока і молочних продуктів. У такій системі типова електрофореграма казеїну істотно відрізняється від тієї, що характерна для протеїнів бобів сої.

К л ю ч о в і слов а: казеїн, електрофорез, ідентифікація протеїнових фракцій, молоко корів.

\section{ИДЕНТИФИКАЦИЯ ПРОТЕИНОВЫХ ФРАКЦИЙ КАЗЕИНОВОГО КОМПЛЕКСА МОЛОКА КОРОВ}

\author{
А. В. Юкало
}

Тернопольский национальный технический
университет имени Ивана Пулюя, Украина;
e-mail: biotech@tu.edu.te.ua

На сегодняшний день известно множество биологически активных пептидов, образующихся в процессе протеолиза различных казеиновых фракций. Использование этого протеинового комплекса, учитывая сложную гетерогенную природу казеина, тесно связано с необходимостью его оперативной идентификации. В связи с этим целью работы было создание электрофоретической системы для быстрой идентификации протеиновых фракций при серийных исследованиях казеинового комплекса молока. Учитывая аномальный характер взаимодействия казеина с додецилсульфатом натрия и близкие значения их молекулярных масс, за основу взята анодная система электрофореза в однородном полиакриламидном геле. В такой системе казеины разделяются по их зарядам и располагаются на электрофореграмме в соответствии с современной классификацией. В качестве дезагрегирующего агента в состав геля добавляется лишь мочевина. На основе проведенных исследований на изготовленном в лаборатории приборе типа Стадиера с изменяемой формой электрофоретической камеры подобраны условия быстрой идентификации казеиновых фракций. При этом был изменен состав геля и сокращен срок определения, что позволило уже через 45 мин идентифицировать основные фракции казеина. Метод может быть полезным для оперативной идентификации казеиновых фракций при их выделении, исследовании, а также при экспрессанализе натуральности молока и молочных продуктов. В данной системе типичная электрофореграмма казеина значительно отличается от электрофореграмм протеинов бобов сои.

К л ю ч е вы е с лов в: казеин, электрофорез, идентификация протеиновых фракций, молоко коров. 


\section{References}

1. Farrell H. M., Jimenez-Flores R., Bleck G. T., Brown E. M., Butler J. E., Creamer L. K., Hicks C. L., Hollar C. M., Ng-Kwai-Hang K. F., Swaisgood H. E. Nomenclature of the proteins of cows' milk - sixth revision. J. Dairy Sci. 2004;87(6):1641-1674.

2. Park Y. W. Bioactive components in milk and dairy products. USA: Wiley-Blackwell, 2009. $426 \mathrm{p}$.

3. Yukalo A. V., Storozh L. A., Yukalo V. G. Cow milk casein complex (Bos taurus) proteins as precursors of bioactive peptides. Biotekhnolohiia. 2012;5(4):21-33. (In Ukrainian).

4. Mayer H. K. Milk species identification in cheese varieties using electrophoretic, chromatographic and PCR techniques. Int. Dairy J. 2005;15(56):595-604.

5. Skalka V. V., Savchuk A. M., Ostapchenko L. I. Determination of different forms of caseins in milk by disc-electrophoresis method. Phys. Alive. 2010;18(3):36-38. (In Ukrainian).
6. Suhaj M., Stankovska M., Kolek E. Quantification of ovine and bovine caseins in Slovakian bryndza ewes' cheese by isoelectric focusing. J. Food Nutr. Res. 2010;49:45-52.

7. Yukalo A., Yukalo V., Shynkaryk M. "Electrophoresis separation of the Milk Protein". Proceedings of the International Conference on Bio and Food Electrotechnologies. Compiegne, France, 2009. P. 227-231.

8. Yukalo V. Obtaining of casein protein complex from cow milk. Nutracos. 2005;5:17-19.

9. Iukalo A. V. New approach for isolation of individual caseins from cow milk by preparative electrophoresis. Adv. Biol. Chem. 2014;4(6):382387.

10. Yukalo V. G., Yavorskyy B. I., Storozh L. A., Solovodzins'ka I. Y. Quantitative electrophoretic analysis of casein complex proteins. Animal Biology. 2007;9(1-2):295-298. (In Ukrainian).

Received 01.03.2015 